\title{
Integrity Value in Local Wisdom (Wayang Sukuraga): Character Education Media Learning in Elementary School
}

\author{
D Lyesmaya ${ }^{1,2}$, A Sutisnawati ${ }^{3}$, L Hamdani ${ }^{4}$, A E Wardana ${ }^{5}$, I Nurasiah ${ }^{6}$, D A Uswatun ${ }^{7}$, \\ A R Amalia 8 \\ $\left\{{ }^{1}\right.$ dyahlyesmaya@upi.edu, ${ }^{2}$ lyesmaya dyah@ummi.ac.id, \\ 3astri212@ummi.ac.id, ${ }^{41}$ uthfihamdani@ummi.ac.id, \\ 6iisnurasiah@ummi.ac.id, ${ }^{7}$ dinazwar@ummi.ac.id, ${ }^{8}$ rizqiaarsyi@gmail.com \} \\ ${ }^{1}$ Universitas Pendidikan Indonesia, Bandung, Indonesia \\ 2,3,2,4,5,6,7,8 Universitas Muhammadiyah Sukabumi, Sukabumi, Indonesia
}

\begin{abstract}
Sukuraga Puppets (Wayang Sukuraga) is a local wisdom puppet show from Sukabumi City, Indonesia. As a culture heritage product, it has a rich art value and impressions. This Article describes Sukuraga Pupets as a media character education to deliver an integrity values for student in Elementary School. This study was survey using an interview and observation. The participant were a Sukuraga Dalang (Sukuraga Pupets player), audiences of sukuraga pupets show from academia, researcher, and public. Based on this study results, Sukuraga Pupets can be use as a media learning to deliver integrity values. In addition, the Sukuraga can be use as an effort to motivate learners in knowing their self being awarness as well as a means for students in making moral action (to express, show, and construct values).
\end{abstract}

Keywords: Integrity, learning media, Sukuraga Puppet, Value.

\section{INTRODUCTION}

The importance of character education is due to the widespread of moral decadence that occures in todays society. Leming recognize it since 1920s ago. He mentioned that valuebased education is needed to gain the moral problem [1]. In Indonesia, the problem of morality triggers the level of crime. More detailed, Suswandari [2] stated that in Jakarta, 1.318 out of 1.647 .835 primary and secondary school children are committed to crime, and this number is growing each year. Up to this point, the need of character education in Indonesia is increasingly high.

Efforts to develop value-based learning models in schools are increasingly sought after by researcher [3]. One of the topics of approach that is increasingly sought after is a learning model that integrates local cultural wisdom. Indonesian researchers began to examine the integration of the curriculum with the value of local wisdom although it has not been maximally explored [4]. However, the guided learning methods [5], and material from local wisdom itself [6] has been developed. They conclude that local wisdom value can be integrated to the teaching learning in school everyday activities. 
Sukuraga Puppets (Wayang Sukuraga) is a product of local wisdom derived from Sukabumi. It is a puppets show about a body part of human being. This is a contemplative wayang about human awareness of his existence as a physical being. Sukuraga means a body part of human. The puppets shows us the conflict of our body part (eyes, mouth, ears, nose, hands, feet, etc.). How they talk, describe, recognize, act, in what tention they solve the conflict and what purposes ore showed in every dialogue betwen the puppets figure. The story of the conflict shows us that, humans display consciousness as wholeness, starting from the awareness that is presented by the body parts. This values will help humans to act morally in a good way. Based on this assumption, the value of Sukuraga is closely related to moral development which must be instilled early on school age.

This value study is important to do because there has no study before about the value of Wayang Sukuraga that could be integrated to the school curriculum. As Susan [7] mentioned that "The visual can play an integrated role in relationship building by opening opportunities for collaboration, meaningful exchanges and achieving commo goals in curriculum.". The relevant studies were only related to the relationship between other local wisdom with the citizenship [8].

\section{RESEARCH METHOD}

This study uses a survey method. The survey was conducted using interview guidelines to dig up information about the perception of responses/responses. The respondents were 10 academics who watched the sukuraga puppet show at the 4th ICEDU (International Conference of Education) in Bangkok, Thailand. The responses were expressed in the form of opinions about what values were conveyed by the Wayang Sukuraga performance. How does perception arise regarding the usefulness of Wayang Sukuraga in the learning process?. Next, watch the Wayang Sukuraga performance independently. After that, we held a discussion with the puppet performance practitioners (Dalang) to find out about the knowledge, beliefs and feelings of the Dalang on the cultural wealth that was exhibited. This interview was conducted for the values contained in the philosophy of Wayang Sukuraga. Information about craft, art from the Sukuraga puppet also needs to be explored to understand and make it parallel with learning media. This can ensure that students/new generations can identify Wayang Sukuraga and its values and possibilities can be conveyed through various learning media, so that they can appreciate and respect their ancestors and cultural riches [12].

\section{RESULTS AND DISCUSSION}

Learning media become an important component in implementing meaningful learning activities for students. Learning media as everything that is used to convey messages from the teacher in a planned manner, to create a good learning environment, in which students can be occure with an effective learning process. Learning media can be divided into as follows.

a) Graphic media, which is a two-dimensional shaped media because it has a length and width. For example: charts, graphs, diagrams, comics, posters, and others.

b) Three-dimensional media, which are artificial media or models smaller than the original or almost the same and can be seen from various angles. For example: stacking models, pop-ups, original objects, and others. Sukuraga puppets are included in the threedimensional media.

c) Projection media, which are media that can be displayed in front of the class using tools (projection). For example: slides, films, videos, OHP, and others. 
d) The environment media, in which students can utilize the environment as learning media. Thus, students will be happier and not feel bored studying in the classroom.

Of the four types of media classifications that are often used, sukuraga puppet media is included in the three-dimensional media, because this puppet is a media or imitation model that is shaped smaller than the original or almost the same. Besides this three-dimensional media can be seen from various directions, both from front-back, right-left, and top-bottom.

Shadow Puppetery has been used by many authors to support learning [9]. The puppets shows become a methode of choice for educating students [10]. The arts can promote theoretical understanding of and valuation of cultural diversity. The arts allow students to experience themselves as empowered and creative individuals moving, making music, creating visual imagery which is both their own and that of another culture they perform-it allows them to imaginatively cross borders [11]. Wayang Sukuraga also has this potential to explore. Teacher will be strong enough to deliver local wisdom value using the development of Wayang Sukuraga as a media learning.

Based on an interview on March 2, 2018 conducted to the puppeteer (Mr. Effendi), the results were obtained as to why the wayang sukuraga used wayang kulit media? Effendi said, "the Raga wayang using skin media is as a union of essence, which in general humans are happy with their skin or facial appearance only ... see when girls are attacked by zits even though only two items are blocked in their faces, they are embarrassed to leave the house , and we also in general to clean the dirt on the skin at least take a shower twice a day, but to cleanse the soul in order to remove the dirty that makes the eyes of the heart unable to see alias blind, how many times a day to water spiritually? do we regularly wash our faces or clothes every day? "

The characters in Wayang Sukuraga are different from other puppets such as Wayang Kulit or Wayang Golek. Wayang Sukuraga has its own identity by not adopting the epic Ramayana or Mahabharata. This certainly affects the storyline played. All characters can be antagonist or protagonist, unlike Wayang Kulit for example where Kurawa is always antagonistic and Kurawa is always protagonist. All figures in Wayang Sukuraga are members of the human body and characterizations are displayed as the function of the limbs in daily life.

Sukuraga Art is divided into two types, namely Wayang Sukuraga and Kudu Leumpang Art. As for the figures of the puppet sukuraga where the characters are bodies or human limbs, such as eyes, nose, ears, mouth, right and left hands, breasts, genitals (vagina, penis), buttocks and legs. However, in the performance of wayang sukuraga characters that are often not only displayed characters such as eyes, hands, nose, ears and feet. Foot figures here are not categorized into sukuraga puppets but instead become Kudu Leumpang art. The following description is about character and characterizations in Sukuraga Art.

The eye (matana) acts as the 'seeing' or the person who has the view. In the core scene the eyes usually appear first before the other figures. There is no difference between the figures of the Right Eye and the Left Eye, all the same, only one character namely Si Mata or The Panon. The distinction in mentioning Si Mata and Si Panon was adjusted to the language when the performance (Sundanese/Indonesian). Eye figures are visually displayed by women and have a feminine character. This is consistently shown by the puppeteer in every performance of Wayang Sukuraga.

Nose (Irung) has a masculine character. Serves as 'who can smell or smell.' In several performances of the Sukuraga Puppet, Si Irung is displayed witty, innocent, and childish. Usually the mastermind speaks buzzing in playing Irung's character. 
Ears (Ceuli) plays the role of the 'listener'. In the performance of Wayang Sukuraga Si Ceuli, he has a strict character and tends to be a protagonist. There is no difference between right and left in this character. Visually displayed Ceuli women. Puppeteers sometimes refer to the Ceuli character as Ceu Eli. 'Ceu or Eceu' in Sundanese means a vocation for women. In the form of Ceuli not only displayed in the figure of the human body but also the figure of a bird.

The mouth (mulutna) in the dominant Sukuraga Puppet is shown antagonist because the mouth often lies to other figures. The mouth is chatty and shown by women puppeteers. In the form of the mouth is not only displayed in the figure of the human body but also the figure of a bird. Mouth is also good at singing.

Right hand (Leungeun Katuhu or Leungka) acts as the protagonist. Often cornered by Left Hand (Leungeun Kenca or Leungke) in the speech of Wayang Sukuraga. Leungka tends to be quiet and innocent. Not much to say but more dominant to move. In several plays Leungka is often shown together with Leungke.

Leungke is the opposite of Leungka. Leungke tends to be the antagonist and bad symbol in the Sukuraga Puppet play. Various immoral acts such as stealing, bribing and accepting bribes, hitting, etc. are carried out by Si Leungke in several scenes of Wayang Sukuraga.

This Breast Figure is almost never shown in the Wayang Sukuraga performance. Although this Breast figure belongs to a member of the body or wayang sukuraga character, but this character is rarely displayed, it can be said as an additional character in the wayang sukuraga. This figure is the same as Breast, which is very rare, in fact it is almost never shown in the performance of Wayang Sukuraga. Visually this figure takes the form of a vital organ of a woman. This figure is in the form of male genitalia modified in such a way that it appears artistic, not vulgar. Same with the figures of Breast, Vagina, and Buttocks, this character is almost never shown in the performance of Wayang Sukuraga. This butt figure is the same as other figures such as breasts, vagina, penis, where the figures are rarely displayed in the Wayang Sukuraga performance.

This foot figure is one of the figures of the sukuraga puppet, but this foot is not used as a puppet, but is called the kudu leumpang (Should Move). Kudu Leumpang is one of the arts of Sukuraga which is also shaped like a foot.

This Wayang Sukuraga is a two-dimensional and three-dimensional medium, which is played by one or more puppeteers. Full control of each puppet is like a shadow puppet. In the form of appearance variations of sukuraga puppets can be either flat or puppet puppets. The media that will be used at the time of research is puppet puppets. The form of the puppet hand puppet itself is in the form of flannelette and cloths that are no longer in use, then made into a hand puppet. The characters used such as hands, eyes, feet, ears, mouth.

A survey was also carried out on several performance audience from different country. The following data were obtained from eleven participants, who is the presenter in $4^{\text {th }}$ ICEDU international conference in Bankok, Thailand.

A speaker from Humpshreys University in the state of California, United States said. "I was very happy to watch the Wayang Sukuraga performance on the night of the 2018 ICEDU seminar. I was extremely impressed with this performance because of the clarity of understanding conveyed by the presenter (Dalang). I was very touched by the puppet itself, and the creativity behind it, also about the explanation and aspects of cultural wealth in it. I explained to the presenter that we, in America, are constantly trying to make the children understand their cultural heritage as a reinforcement of understanding of their educational needs. This performance helped me, reminded myself, of the importance of cultural heritage in meeting the strengthening of education and care for them (children). So, congratulations. Very good work and thank you for giving me the opportunity to give this testimonial. " 
Other speakers from this university are female lecturers. She said "What I like the most is especially about the metaphors of wayang, which is not someone who does something but about the ears, the mouth that clearly displays the value of a culture and its affirmation of the activity of thinking first before speaking and how to listen. I really enjoyed this aspect. Thank you."

Next is a female lecturer from Faisalabad State University, Pakistan. "I came to attend two international seminars this year. The Wayang Sukuraga performance that I witnessed last night was extraordinary. Something about which part of the body came first or later caught my attention. We must be thankful that we have the perfect shape and we must use each of our organs in an appropriate way. Think before we speak so we don't hurt each other. I really enjoyed this and would like to meet again with this team, because for me it was extraordinary. The Wayang Sukuraga performance that I witnessed last night was extraordinary. The context behind this performance is extraordinary. Which part of the body should come first ... I think ... that ... we must think before we speak. We must use appropriate and appropriate language and words so as not to attack others. I think this is the best show. Thank you very much for showing this to us and others too."

In contrast to the previous presentation, independent researchers from the United States, who obtained Doctorates from Drew University of America and Wenzhou-Kean University of China. He said, "I am very impressed with the Sukuraga puppet. How to show it, the dynamics in the whole story, I feel it is very valuable to be adopted and hope that one day I can visit Indonesia and observe how the Wayang (Sukuraga) works in the classroom. And hope we have collaborative work together. I mean we can expand the scope for example by maintaining the continuity of the world as a peaceful and pleasant place for children and for those with developmental disabilities or disabilities for example, or whatever it is ... that we have work to provide whatever needs for them (children). "

Starting with that, a professor from the University of Gehnt, Belgium said "this is very important to me because this form (puppet) can give children and teach them about the idea that you have eyes but can also see with your hands, by touching and manipulate something in learning, and this is like a new eye you have. You keep your feet, you can walk, you can dance, you can move, and once again this becomes a path for learning. So, thank you. This is a unique experience. I like it, and I will record it with me for my country. Thank you."

While a female lecturer from National University og Modern Languages, Pakistan said "I see your puppet program is a very good idea to teach children about values with the help of various body parts (Sukuraga). Which parts of the body do what tasks, and what should they (these body parts) do?. I think, this is more about moral education with good speech. Very good job. Congratulations. "“

A male English teacher from Russia believes "today I have the opportunity to see very good performances, puppet shows, and what's interesting is that these good people use puppet shows to teach English to students. This is not the usual way and a very good way, because children can see a variety of different body parts. And they can see what if the body part is in another place (not in the right place). This is very interesting. I wish you success in teaching and in your life."

A Chairman \& CEO of The International Institute of Knowledge Management, Srilanka added: "Yes this actually explains to us the meaning of this puppet, how we use it for the benefit of Educational purposes. Actually ... we need ... I'm Oshadee from Srilanka ... I mean we need to know about the high quality and technology used in Education ... because it seems simple. But actually in Education simplicity (simple = easy to digest) is the most important thing. The symbolization of speaking, (this puppet), the mouth, which is under the eye, and 
does not stay or is higher than the eye, symbolizes that we must see, we must think before speaking. This is an interesting topic, and a way of teaching that appeals to anyone. We believe that the context of this technology must be developed and how it looks, as well as how it is used for modern education. Thank you."

while the Co-Founder \& Managing Director of The International Institute of Knowledge Management, Srilanka said: "What did you do at this dinner, how do you educate children using this Wayang (Sukuraga), and about the concept WOW ... I am very impressed with eyes in your hand, what you will do is only the best (best) thing. Is this made of traditional material? Yes, made of leather, alright. "

And finally, a participant from Kuwait. He said: "I watched your performance (Sukuraga). This puppet is very beautiful and has many benefits for children. Because God created this part of the human body is very very important for us. Maybe some people ignore this part of the body. We only realize this part of the body when it hurts. So it's a good idea to teach kids about this. I hope we can meet again next time. Thank you."

\section{CONCLUSIONS}

History proves that the development of character and culture of a nation can never breaks away from the traditional values that have underpinned and raised it. The history of the nations of the world shows that a developed and large nation has roots in the mythological tradition. Mythology is the crystallization of concepts, values, and norms that animates people's attitudes towards life and causes communication between members of the community to be efficient. Wayang stories are works of art that are valuable, monumental, and very valuable, not only because of the greatness of the story, the beauty of the delivery, the firmness of character patterns, but also the value of philosophies and "teachings" that are priceless and are still relevant to the present situation.

The use of the Wayang Sukuraga art form gives concrete meaning in giving identity to certain communities or societies. Wayang Sukuraga is the preservation of culture in the context of an education of moral simplicity for everyone, especially children in school. The preservation of culture in question is the Wayang Sukuraga as cultural heritage that shows the character of a society along with the increasingly rapid digital development. While moral simplicity education is reflected in the message conveyed by the puppet, using the five senses in accordance with the basic objectives. The eyes are located above the mouth, meaning that before developing an opinion it is better to use the eyes as validation whether the opinion is appropriate. An ingredient for self-reflection in the formation of character. Wayang Sukuraga can be a learning medium to deliver the value of integrity in elementary schools.

\section{REFERENCES}

[1] J. S. Leming, "Cheating behavior, subject variables, and components of the internalexternal scale under high and low risk conditions," J. Educ. Res., 1980.

[2] Suswandari, "Incorporating beliefs, values and local wisdom of Betawi culture in a character-based education through a design-based research," Eur. J. Contemp. Educ., vol. 6, no. 3, pp. 574-585, 2017.

[3] G. M. Almerico, "Building character through literacy with children's literature," Res. High. Educ. J., vol. 26, pp. 1-13, 2014.

[4] R. Hadi, S. Supriyanto, and M. Hasanah, "Economic Learning Media Development Based on Local Locality," Int. J. High. Educ., vol. 6, no. 3, p. 188, 2017. 
[5] P. T. Anggraini, "Character and Local Wisdom-Based Instructional Model of Bahasa Indonesia in Vocational High Schools," J. Educ. Pract., vol. 8, no. 5, pp. 23-29, 2017.

[6] S. Uge, A. Neolaka, and M. Yasin, "Development of social studies learning model based on local wisdom in improving students' knowledge and social attitude," Int. J. Instr., vol. 12, no. 3, pp. 375-388, 2019.

[7] S. R. Whiteland, "Exploring Aging Attitudes Through a Puppet Making Research Study," Int. J. Educ. Arts, vol. 17, no. 3, pp. 1-30, 2016.

[8] I. Setiawan, A. Tallapessy, and A. Subaharianto, "Exertion of Cultures and Hegemonic Power in Banyuwangi: The Midst of Postmodern Trends," KARSA J. Soc. Islam. Cult., vol. 25, no. 1, p. 147, 2017.

[9] P. Gray, A. C. Rule, A. Gentzsch, and D. A. Tallakson, "Shadow Puppet Plays in Elementary Science Methods Class Help Preservice Teachers Learn about Minority Scientists," J. STEM Arts, Crafts, Constr., vol. 1, no. 1, pp. 27-45, 2016.

[10] C. J. Dunst, "Effects of puppetry on elementary students' knowledge of and attitudes toward individuals with disabilities," Int. Electron. J. Elem. Educ., vol. 4, no. 3, pp. 451-457, 2012.

[11] K. Foley, "Wayang and Gamelan as a Tool of Cultural Learning: Indonesian Puppets, Dance and Music in the Classroom," J. Learn. through Arts, vol. 1, no. 1, 2005.

[12] K. Saddhono and M. Rohmadi, "A Sociolinguistics Study on the Use of the Javanese Language in the Learning Process in Primary Schools in Surakarta, Central Java, Indonesia." Int. Edu. Stu., vol. 7 no.6 pp 25-30, 2014 